\title{
A Study on the Factors Influencing Consumers' Purchase Intention Towards Chinese Beauty Industry: Focusing on SNS Characteristic Elements
}

\author{
Jing $\mathrm{Xu}^{1}$, Ha-kyun $\mathrm{Kim}^{2}$ \\ ${ }^{1}$ Graduate School of Information Systems, Pukyong National Univ., 45, Yongso-ro, \\ $\mathrm{NamGu}$, Busan, Korea \\ ${ }^{2}$ Division of Business, Pukyong National Univ., 45 Yongso-ro, NamGu Busan, \\ Korea \\ ${ }^{1}$ strangerrr0301@gmail.com; ${ }^{2} k i m h k @ p k n u . a c . k r$
}

\begin{abstract}
Digital technology is accelerating the upgrade of the consumer market and becoming a lever of China's consumer economy. It amplifies the purchasing power of Chinese consumers and fissures new consumer market structures and consumer behaviors. Consumer groups of different ages are active on SNS, showing a distinctive and traditional consumption outlook. Price, quantity, new products, trademarks, and the degree of displayability are no longer the main criteria for choosing a product. What to buy, where to buy, why, and how to share on SNS after shopping has received more attention.

In China, nearly $90 \%$ of consumers have their own SNS circle, and it is most common to share information on beauty, clothes, food, travel, etc. About $87 \%$ of consumers are willing to share their shopping experience or comment with others, and $55 \%$ of them will share their actual shopping in SNS. This part of consumers is more susceptible to the influence and stimulation of SNS sharing, thereby increasing their willingness to buy. Consumption presents a circular chain reaction of "purchase-share-repurchase". SNS has a considerable influence on consumer buying behavior. Chinese consumers believe that word of mouth is more than anything else. Most consumers are more willing to believe in and buy the products recommended in SNS, even if the price is high. All kinds of recommendations and sharing on SNS stimulate the curiosity and willingness of the onlookers to buy.

The characteristics of SNS are the underlying factors that influence brand trust and consumer purchase intention. This thesis examines the impact of SNS features on Chinese consumers' purchase intentions, by reviewing and analyzing prior research, interactivity, access convenience and recency. The study empirically analyzed the data through SPSS 22.0 and Smart PLS2.0 (Structural Equation Package) to test the hypotheses. The results of hypothesis 1 are as
\end{abstract}


follows: First, the interactivity of SNS positively influences brand trust. Second, the access convenience of SNS positively influences brand trust. Third, the recency of SNS has a positive impact on brand trust. The results of hypothesis 2 stated that brand trust positively influences consumer purchase intention. Finally, the research limitations and future research directions of this thesis are pointed out.

Keywords: Sns characteristics, interactivity, access convenience, recency, brand trust, purchase intentions

\section{Introduction}

With the continuous improvement of Internet infrastructure and the rapid development of mobile terminal technology, mobile Internet is playing an increasingly important role in public life. According to the Statistical Report on the Development Status of the Internet in China published by China Internet Network Information Center (CNNIC) in February 2021, the Internet access rate of Chinese people reached $70.4 \%$, with the total number of people accessing the Internet being about 989 million, of which $99.7 \%$ of the mobile phone users were online on mobile terminals, with the number reaching 986 million. Also, the latest CNNIC report data points out that the number of Chinese online shopping users is about 782 million, accounting for $79.1 \%$ of the overall number of Internet users, of which mobile phone online shopping users are about 781 million, accounting for $99.9 \%$ of the total number of online shoppers.

The popularity of mobile Internet and smartphones has made it possible for people to exchange and interact with information online anytime and anywhere. This has greatly changed the way people interact and communicate with each other socially, while also bringing about a revolutionary change in traditional social media, and mobile social media was born. As an emerging information exchange platform, mobile social media uses big data and deep learning technology to achieve mobile location-based services, personalized search, personalized recommendations, and instant messaging, greatly catering to users' needs for social entertainment and information communication in different scenarios. Based on this, users of traditional online social networking sites have started to migrate to mobile social media applications in large numbers, and the mobile social industry has flourished, with mobile social media platforms becoming a mainstream online communication and information exchange tool for people.

With the development of the Internet and smart terminal technology, SNS not only supports the use of computers, but also allows users to access SNS using their mobile phones, making it more convenient and free for users to share information, such as text, images and videos, etc. The SNS has developed into an important channel for consumers to obtain and share information. At the same time, traditional marketing has begun to transform. By using mobile internet, SNS has begun to gather a large number of user resources and the way consumers obtain information 
has shifted from passive acceptance to active acquisition. Chinese consumers' consumption attitudes have shifted from survival to enjoyment, and the Chinese market has thus reached a new level of consumption. Under the new consumption model, consumers are getting more information from social interaction channels, using various social media, social software and social platforms such as SNS and WEIBO to interact socially with unfamiliar consumers, so that users' comments and published information can influence other consumers' perceptions of products.

Nowadays, consumers no longer single-handedly shop on traditional shopping sites, but open active exploration mode. Consumers will get their path to purchase through online search engines, search for desired products on SNS, and check information posted by other consumers on SNS, e.g. text, pictures, short videos, etc. Consumers can make purchase decisions based on information posted by other users. As shopping information becomes more transparent, the behavior of comparing prices is becoming more and more popular, showing a "digital imprint." About 50\% of consumers said they would often use mobile phones to compare prices when shopping offline, and $45 \%$ said they would often use SNS to find lower prices. What needs to be pointed out here is that consumers "shop around" are no longer seeking lower prices, but will compare all aspects of the product information and become a "smart consumer". Consumers use SNS to connect with other consumers and exchange post-purchase experiences, experiences in gathering information and experiences in communicating with unfamiliar users on SNS, etc. Consumers will judge the value of products based on the information posted by other consumers and eventually make purchasing decisions. It is also possible for companies to get feedback from users in a cost-effective way, so that they can obtain some valuable suggestions.

In recent years, the trend of consumer socialization has become more obvious, and shopping has become a by-product of social life. This phenomenon is more pronounced among young and high-income groups; and in this trend, the more and more subdivided SNS circles, the power of SNS sharing is the most influential. In the "SNS economy", it can be said that the more sharing and the more impulsive, the easier it is to generate purchase intentions. With the upgrading of consumption and the improvement of consumers' focus and needs, consumers pay attention to the experience in the process of searching, viewing information and evaluation on SNS, initiating participation in discussions, making purchases, and sharing shopping experiences. SNS is the platform foundation of social e-commerce, and its technical characteristics are the core driving force of social e-commerce. SNS feature factors, as features that meet user needs, are not only a deep-seated reason that affects consumers' purchase intentions, but also factors that affect consumers' online experience. What kind of influence SNS has on consumers' purchase intention is worthy of in-depth exploration. 


\section{Theoretical Background}

\subsection{SNS System Characteristic}

SNS stands for 'Social Network Service' and can be thought of as a service for building interpersonal networks. SNS refers to an online platform that establishes and strengthens social relationships by sharing information and expanding interpersonal networks and free communication between users. The most important part of SNS is that it creates, maintains, strengthens and expands social networks through SNS services (Kim and Kim, 2015). It is possible to strengthen relationships with colleagues, schoolmates, friends online. In addition to this, new relationships can be established, for example, through SNS, which can form a rich network of people and allow for interpersonal communication (Jeon, 2017). In other words, it makes more sense when sharing and distributing information through SNS networks.

Scholars have studied and defined the characteristics of SNS in a variety of ways. The particularity of SNS is that it goes beyond the concept of simple information acquisition and becomes a place for people to gather and communicate, due to the fact that information or content can be generated through interaction and conversation between SNS users. One of the reasons why people prefer SNS is that relationships that were previously centred offline are now expanding online, precisely because of the unique characteristics of SNS, which allow networking between companies and customers (including those around them) without the constraints of time and space (Kim and Kim, 2015). In addition, SNS are based on human-centred principles, allowing users to communicate with each other. Everyone can become friends through SNS offline. During communicating online, SNS can be a source of information while people can feel socialized, empathetic and emotional. It connects people beyond time and space (Jeon, 2017).

SNS expresses social relationships as nodes and links or relationships that represent individuals, that is, relationships between individuals. It refers to the realization of a social structure that can be implemented as an online community[4]. SNS allows individuals to establish personal information in the form of public or conditional disclosure within a limited Web-based system, and to establish a list of organic associations with other users who share relationships. It also allows you to view lists built by other users in the system. Some research related to SNS characteristics are focusing on the relationship characteristics of SNS. Based on the interaction, social existence, and exchange attributes of SNS based on the relationship between people, the distribution and aggregation of content has become easier and faster, and the cost and time required for consumer participation and dissemination have become cheaper (Kim and Kim, 2015). Based on previous scholars' definition of the concept of SNS, this research defines SNS as a communication method that can communicate with consumers in real time. 


\subsubsection{Interactivity}

Interactivity refers to all the various actions of two-way communication that take place between the sender and the receiver of a message (Choi, 2017). The more frequently users communicate with each other, the more the bond between users rises, the more individual views and suggestions are recognized by the group, and the more frequently users use the service, which is a factor in increasing the length of time spent online. Interactivity in SNS is based on communication, where people can exchange conversations online by commenting, replying and sharing. The exchange of information and experiences through SNS allows anyone to become an original creator and consumer of content (Park, 2019). Interactivity is not only manifested in the communication between consumers and the SNS platform, but also in SNS provides companies, brands and merchants with a platform that can directly communicate with consumers, which is conducive to brands and merchants to quickly understand the real consumers. Through SNS, companies can deliver marketing messages directly to consumers, while having the advantage of getting feedback from consumers in a cost-effective manner (Choi, 2017).

Interactivity not only allows SNS users to actively select content, but also to participate directly in exchanges with other users. This interactivity allows consumers to autonomously customize content to suit their needs and provides more advanced personalization through data analysis (e.g. consumers' personal information, location and purchase history). These services make consumers more likely to make purchases and have a positive impact on product acquisition and business performance (Yoo, 2019).

\subsubsection{Access Convenience}

Accessibility refers to effective navigation, search and easy interface structures on website pages that allow users to find the information they need efficiently and accurately. In addition, accessibility can also be defined as ensuring that SNS are accessible to everyone, even if users do not have specialized skills; conversely, social exclusion may occur if users do not know how to use the web (Liu, 2018).

Shim \& Mahoney (1991), in their study on customer's intention to use online shopping, showed that users who have easy access are more likely to use online shopping. Therefore, the access convenience of users to SNS can be justified by the same logic. Since SNS requires very few clicks to easily perform most operational functions, many users maintain a lasting relationship with SNS. The easier it is for users to access the SNS, the more positive the customer's relationship with the product and the greater the customer's confidence in the product.

Users want SNS to provide high-quality information and services. If the data transmission is not smooth enough and the page conversion speed or access is inconvenient, users will have an unstable view of SNS and will look for another SNS to replace the corresponding SNS. Therefore, the ease of use when using SNS marketing is an important factor (Liu, 2018). Based on the definition of accessibility 
by previous scholars, this research defines accessibility as easy to use without complicated procedures when using SNS services.

\subsubsection{Recency}

Recency refers to the ability to quickly handle downloading, updating and modifying content on a website or mobile device, with the ability to provide information, one-way communication with immediacy in a mobile device (Oh and Kim, 2014). The greater the amount of information updated on the SNS, the more quickly it is updated, representing the majority of consumers who buy the product, creating a social impact that makes the mass of consumers recognize the quality of this product and attracts them to make a purchase.

Recency is the degree to which consumers are provided with the latest product information and the degree of continuous updating of the information provided at the same time as the product is released. Today, when the product life cycle is shortened and various products are released in a short time, it is very important to send and receive the latest information quickly, and it is very important to provide information in a timely manner at the correct time when consumers need it $(\mathrm{Li}$, 2016). The integrity, ease of understanding, personalization, relevance, recency and safety of information determine the attitude of consumers. The more timely the information, the more the attitude changes in the expected direction. Recipients are also more likely to accept the latest information, so timely update is a very important feature (Oh and Kim, 2014). The fundamental purpose of a website is to deliver information, and depending on the quality of the information, users will naturally give feedback on how they feel about using the website (Li, 2016). Therefore, website information should be reliable, recent, and easy to understand so that users will be more loyal. Recency information influences consumer behavior. The quicker and more reliable information increases consumer acceptance the more perceived value it would have, which in turn influences consumer behavioral tendencies (Oh and Kim, 2014). Based on the definition of the concept of recency by previous scholars, this research defines recency as the rapid provision of the latest information needed by SNS users.

\subsection{Brand Trust}

Spence (1973) said that the essence of a brand is the signal that a good sends to consumers, a mechanism by which a company communicates information about its goods to consumers. Here, the signal refers to observable actions taken by a company that can convince consumers of the quality or value of its products.

Brand trust can be defined as consumers experiencing the brand's products or services, relying on the brand's ability to make product purchase decisions, and then trusting the brand. It is the foundation for establishing a positive relationship between the company and consumers, and for consumers to have a sense of immersion and loyalty to the brand, which can enable the two to have more stable 
and sustainable growth. Brand trust has a foundational character in social environments that require cooperation and interdependence. As it is formed through, for example, observation of each other and past interaction experiences, long-term satisfaction is an important factor in the formation of trust (Kim, 2020). Brand trust is an important factor in encouraging customers to spend money, while at the same time providing comfort and satisfaction. Especially in an online shopping environment, customers may feel various risks and anxieties, but trust reduces negative customer emotions (Pei, 2017). In the "Study on the Influence of Brand Trust on the Formation of Consumer-Brand Immersion Relationships", it was discovered that brand trust can influence consumers to make some sacrifices for brand consumption and use. If customers are dissatisfied because the brand does not perform as expected, customer confidence and trust in the brand will be diminished (Kim and Choi, 2014). Based on the definition of the concept of brand trust by previous scholars, this research defines brand trust as the trust that consumers have in the brand through corporate SNS marketing.

\subsection{Purchase Intention}

Purchase intention is a mediating variable between attitudes and behavior and is a frequent predictor of consumer behavior in research in the marketing field. It serves as a link between buying attitudes and buying behavior in understanding consumers' buying behavior, whether a consumer buys a product is more influenced by purchase intention than purchase attitude (Jun et al., 2014). The consumer's purchase intention can be seen as the willingness to buy a product and is a decisive factor that directly influences purchase behavior and can therefore be said to be the consumer's expected planned future behavior (Kim and Lee, 2020). Purchase intention indicates the consumer's willingness to perform a specific act of purchasing a product in the future. It can be judged by whether an individual has the willingness to take action on a specific issue. In addition, the higher the product price and product participation, the greater the possibility of actual purchase behavior and is an important variable in measuring a company's performance (Tian and Lee, 2020).

Purchase intention is a measure of consumer willingness to buy by identifying consumer demand for a product. Purchasing intention is a field of behavioral intention, which is the personal will and belief realized by the result of future behavior such as the attitude formed by an individual towards a specific company. There is a close positive correlation between purchase intention and actual purchase behavior. Therefore, purchase intention can be used as a predictor of actual purchase behavior. It can also be said that when consumers decide whether to purchase a product, the influence of their purchase intention is greater than their attitude towards the product itself (Wu and Lee, 2020). Purchase intention is considered to be the intermediate process between consumers' attitudes to purchase and the actual purchase behavior, and consumers' personal intentions lead to future 
purchases (Jung and Kim, 2020). Most consumers learn about the products they need based on their personal needs and conduct an information search, and the search process is highly likely to elicit purchase intentions through the influence of advertising (Ju and Jung, 2019).

Purchase intention refers to the extent to which consumers are willing to purchase in marketing. In other words, beliefs may be transformed into actions. As consumers' expected behaviors in the future, there is a positive correlation between purchase intentions and purchase behaviors. Therefore, the purchase intention is a stage before the purchase behavior. It can be said that the "purchase intention" has more influence on the consumer's purchase than the "attitude" towards the product itself. In this research, purchase intention is defined as the willingness to purchase goods and services under the influence of SNS characteristics and brand trust (Tian and Lee, 2020). Therefore, in this study, a research model with purchase intention as the final variable is proposed.

\section{Research Model And Research}

\subsection{Research Model}

The purpose of this thesis is to focus on Chinese consumers' intention to buy in the beauty industry based on the characteristic elements of SNS, which can be classified as interactivity, access convenience and recency. Based on prior research the brand trust and purchase intention can be derived from the research model shown in Fig. 1.

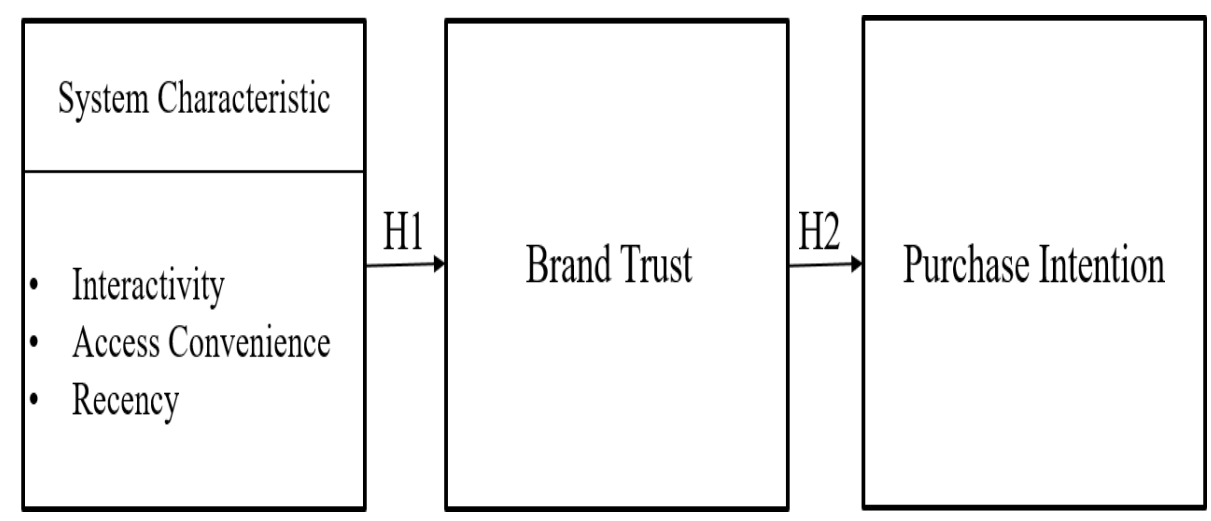

Fig. 1: Research model.

\subsection{Research Hypothesis}

\subsubsection{Features of SNS and Brand Trust}

In this study, the characteristic elements of SNS will influence Chinese consumers' trust in products and intention to purchase. The characteristics of SNS are interactivity, access convenience and recency, which enable consumers of beauty 
products to share product information and service information, thus helping consumers to make rational choices (Xu et al., 2021). Based on prior research, this study establishes the following hypotheses in order to test how the characteristic elements of SNS affect consumers' trust in brands.

Hypothesis H1-1: The interactivity of SNS has a positive (+) impact on brand trust.

Hypothesis H1-2: The access convenience to SNS has a positive (+) effect on brand trust.

Hypothesis H1-3: The recency of SNS has a positive (+) effect on brand trust.

\subsubsection{Brand Trust And Purchase Intention}

Consumer trust in a brand is an important determinant of purchase intentions, because consumers first have to trust the brand before deciding to buy the product (Kim and Cho, 2016). Based on prior research, this thesis establishes the following hypotheses in order to verify how brand trust affects consumers' purchase intentions.

Hypothesis H2: Brand trust has a positive $(+)$ impact on consumers' purchase intentions.

\subsection{Operational Definition of Variables}

The purpose of this study is to examine the effect of SNS characteristics on the purchase intention of Chinese beauty industry consumers as a medium of brand trust.

In principle, the measurement variables used in this study were to use the measurement items that have proven reliable and valid in previous studies, and some items were used after modification according to the purpose of this study.

The operational definition of the terms used in the study are shown in Table 1.

\subsection{Operational Definition And Measurement of The Variables}

In order to analyze the impact of SNS characteristics elements on purchase intentions, the questionnaire contains 5 concepts and 18 questions including interactivity, access convenience, recency, brand trust and purchase intentions. The remarks "strongly disagree", "disagree", "general", "agree" and "Strongly Agree" are given $1,2,3,4,5$ points respectively.

Interactivity refers to all actions that occur between the sender and receiver of a message in a two-way communication. In this study four questions were designed to investigate interactivity.

Access convenience refers to the effective navigation, search and easy interface structure on the website pages that allows users to find the information they need efficiently and accurately. In this study four questions were designed to investigate access convenience.

Recency refers to the ability to quickly handle downloading, updating and modifying content on the website or mobile devices. In this study, three questions 
were designed to investigate recency.

Table 1: Operational Definition of Study Variables and Related Studies

\begin{tabular}{|c|c|c|}
\hline $\begin{array}{c}\text { Variable } \\
\text { Name }\end{array}$ & Operational Definition & References \\
\hline SNS & $\begin{array}{l}\text { SNS is an Internet-based service that allows individuals } \\
\text { to form a community within a system, open their shared } \\
\text { networks, and support others' networks. }\end{array}$ & $\begin{array}{c}\text { Kim and Kim, } \\
2015\end{array}$ \\
\hline Interactivity & $\begin{array}{l}\text { Interactivity refers to all the various actions of two-way } \\
\text { communication that take place between the sender and } \\
\text { the receiver of a message. }\end{array}$ & Choi, 2017 \\
\hline $\begin{array}{c}\text { Access } \\
\text { Convenience }\end{array}$ & $\begin{array}{l}\text { Accessibility refers to effective navigation, search and } \\
\text { easy interface structures on website pages that allow } \\
\text { users to find the information they need efficiently and } \\
\text { accurately. }\end{array}$ & Liu, 2018 \\
\hline Recency & $\begin{array}{c}\text { Recency refers to the ability to quickly handle } \\
\text { downloading, updating and modifying content on a } \\
\text { website or mobile device, with the ability to provide } \\
\text { information, one-way communication with immediacy } \\
\text { in a mobile device. }\end{array}$ & $\begin{array}{c}\text { Oh and Kim, } \\
2014\end{array}$ \\
\hline Brand Trust & $\begin{array}{l}\text { Brand trust can be defined as consumers' dependence } \\
\text { on the brand's ability to make product purchase } \\
\text { decisions. It is the foundation for building a positive } \\
\text { relationship between the company and consumers, and } \\
\text { it makes consumers feel immersed and loyal to the } \\
\text { brand. }\end{array}$ & Kim, 2020 \\
\hline $\begin{array}{l}\text { Purchase } \\
\text { Intention }\end{array}$ & $\begin{array}{l}\text { Purchasing intention refers to the expected or planned } \\
\text { future behavior of consumers, and the possibility of } \\
\text { transforming an attitude into action. }\end{array}$ & $\begin{array}{c}\text { Jung and Kim, } \\
2020\end{array}$ \\
\hline
\end{tabular}

Brand trust is the process of developing trust in a brand as a result of learning about a product or service. Here, three questions were designed to investigate brand trust.

Purchase intention is the intention of the consumer to purchase a product and helps to understand the consumer's purchasing behavior. In this study, four questions were designed to investigate purchase intention.

\section{Empirical Analysis}

\subsection{Data Collection}

This study was empirically analyzed by means of a questionnaire survey. The questionnaire survey was conducted in collaboration with a Chinese questionnaire 
company and targeted Chinese consumers online. The survey started on 1 March 2021 and lasted 11 days. A total of 200 questionnaires were distributed, 33 invalid questionnaires were deleted, and 167 valid questionnaires were returned.

Table 2: Operational Definition and Measurement Items

\begin{tabular}{|c|c|c|c|}
\hline \multicolumn{2}{|c|}{ Variables } & Details & $\begin{array}{l}\text { Prior } \\
\text { Study }\end{array}$ \\
\hline \multirow{3}{*}{$\begin{array}{c}\text { SNS } \\
\text { System } \\
\text { Charact- } \\
\text { eristic }\end{array}$} & $\begin{array}{c}\text { Interacti- } \\
\text { vity }\end{array}$ & $\begin{array}{l}\text { - Many communication opportunities can be obtained } \\
\text { through SNS } \\
\text { - You can exchange opinions with other users through } \\
\text { SNS } \\
\text { - Through the sharing of SNS, users can resonate with a } \\
\text { certain product } \\
\text { - Through the exchange of SNS, you can form a social } \\
\text { network with other users }\end{array}$ & $\begin{array}{c}\text { Park, } \\
2019 ; \\
\text { Liu, } \\
2018\end{array}$ \\
\hline & $\begin{array}{c}\text { Access } \\
\text { Convn- } \\
\text { ience }\end{array}$ & $\begin{array}{l}\text { - The registration and login method of SNS is very } \\
\text { simple } \\
\text { - The operation method of SNS is very simple } \\
\text { - You can easily search for the information you want } \\
\text { - Interested content on SNS can be easily saved and } \\
\text { shared }\end{array}$ & $\begin{array}{c}\text { Park, } \\
2019 ; \\
\text { Liu, } \\
2018\end{array}$ \\
\hline & Recency & $\begin{array}{l}\text { - The product information provided by SNS will be } \\
\text { updated in time } \\
\text { - SNS will promptly push the information I am interested } \\
\text { in } \\
\text { - SNS will update the user's communication information } \\
\text { (comments, messages, etc.) in a timely manner }\end{array}$ & $\begin{array}{l}\text { Park, } \\
2019\end{array}$ \\
\hline \multicolumn{2}{|c|}{ Brand Trust } & $\begin{array}{l}\text { - Through the introduction of SNS, I have a good } \\
\text { impression or trust in a certain brand } \\
\text { - I believe a certain product information provided on } \\
\text { SNS } \\
\text { - Compared to other brands, I prefer brands that I often } \\
\text { follow on SNS }\end{array}$ & $\begin{array}{c}\text { Park, } \\
2019 ; \\
\text { Kim, } \\
2020\end{array}$ \\
\hline \multicolumn{2}{|c|}{ Purchase Intention } & $\begin{array}{l}\text { - You can get information about the products you want to } \\
\text { buy or use on SNS } \\
\text { - Through the introduction of SNS, I will buy or use a } \\
\text { certain product } \\
\text { - I will buy or use a product on SNS } \\
\text { - Products purchased or used through SNS, I would } \\
\text { recommend others to buy or use }\end{array}$ & $\begin{array}{c}\text { Park, } \\
2019 ; \\
\text { Kim, } \\
2020\end{array}$ \\
\hline
\end{tabular}


Of the 167 valid questionnaires returned, $29.94 \%$ were male and $70.06 \%$ were female, which is an unbalanced ratio between men and women, as people who consume on SNS are generally users who have a strong need for product information and are willing to actively spread and share information, so female consumers are generally in the majority. The age of respondents is mainly concentrated between 20-39 years old, accounting for 79.04\%, which also reflects that young people are the main group of SNS users, as they are willing to collect and share information, and have a stronger demand for product information. Among the respondents, 50.9\% had a university degree or above. As the income level of young people, who are the main user group, is not very high, their income is mostly concentrated below RMB 5,000, accounting for 58.09\% of the total proportion. Based on these, the sample distribution of this study fits the reality, and samples are also representative.

\subsection{Data Analysis Method}

For the survey analysis, SPSS 22.0 and Smart PLS2.0 (Structural Equation Package) were used for the basic statistics. Centralized validity was examined for each factor for factor loading values, component reliability (CR) and variance extraction index values (AVE), typically with factor loading values equal to or greater than 0.6, component reliability values equal to or greater than 0.7 and variance extraction index values of 0.5 or greater. As a result of comparing the square root value of the variance extraction index value to the correlation coefficient, discriminant validity is not an issue for discriminant validity as the variance extraction index value is greater than the vertical and horizontal correlation coefficient values. In this study, the measurement model was analyzed first before the structural equation analysis was conducted to carry out the reliability and validity analysis of the research model as shown in Table 4.

Table 3: Demographic Characteristics $(n=55)$

\begin{tabular}{|c|c|c|c|}
\hline \multicolumn{2}{|c|}{ Item } & Frequency & Ratio(\%) \\
\hline \multirow{3}{*}{ Gender } & Male & 50 & 29.94 \\
\cline { 2 - 4 } & Female & 117 & 70.06 \\
\hline \multirow{5}{*}{ Age } & Under 20 & 2 & 1.2 \\
\cline { 2 - 4 } & $20 \sim 29$ & 68 & 40.72 \\
\cline { 2 - 4 } & $30 \sim 39$ & 64 & 38.32 \\
\cline { 2 - 4 } & $40 \sim 49$ & 20 & 11.98 \\
\cline { 2 - 4 } & 50 59 & 12 & 7.19 \\
\cline { 2 - 4 } & Over 60 & 1 & 0.6 \\
\hline \multirow{5}{*}{ Education } & Below high school & 43 & 25.75 \\
\cline { 2 - 4 } & Graduated from high school & 39 & 23.35 \\
\cline { 2 - 4 } & University graduation & 61 & 36.53 \\
\hline
\end{tabular}




\begin{tabular}{|c|c|c|c|}
\hline & Master or PhD & 24 & 14.37 \\
\hline \multirow{4}{*}{ Job } & Student & 13 & 7.78 \\
\cline { 2 - 4 } & Staff & 60 & 35.93 \\
\cline { 2 - 4 } & Civil servants & 12 & 7.19 \\
\cline { 2 - 4 } & Businessman & 9 & 5.39 \\
\cline { 2 - 4 } & Housewife & 22 & 13.17 \\
\cline { 2 - 4 } & No job or Freelance & 29 & 17.37 \\
\cline { 2 - 4 } & Other & 22 & 13.17 \\
\cline { 2 - 4 } & & & \\
\hline
\end{tabular}

Table 4: Reliability and Internal Consistency

\begin{tabular}{|c|c|c|c|c|c|}
\hline \multicolumn{2}{|c|}{ Variable name } & $\begin{array}{c}\text { Factor } \\
\text { Loading }\end{array}$ & AVE & $\begin{array}{l}\text { Composite } \\
\text { Reliability } \\
\end{array}$ & $\begin{array}{c}\text { Cronbach's } \\
\text { Alpha } \\
\end{array}$ \\
\hline \multirow{4}{*}{ Interactivity } & INT1 & 0.813 & \multirow{4}{*}{0.690} & \multirow{4}{*}{0.899} & \multirow{4}{*}{0.852} \\
\hline & INT2 & 0.894 & & & \\
\hline & INT3 & 0.785 & & & \\
\hline & INT4 & 0.826 & & & \\
\hline \multirow{4}{*}{$\begin{array}{c}\text { Access } \\
\text { Convenience }\end{array}$} & $\mathrm{ACC} 1$ & 0.704 & \multirow{4}{*}{0.647} & \multirow{4}{*}{0.879} & \multirow{4}{*}{0.820} \\
\hline & $\mathrm{ACC} 2$ & 0.840 & & & \\
\hline & ACC3 & 0.772 & & & \\
\hline & ACC4 & 0.891 & & & \\
\hline \multirow{3}{*}{ Recency } & REC1 & 0.838 & \multirow{3}{*}{0.741} & \multirow{3}{*}{0.896} & \multirow{3}{*}{0.827} \\
\hline & REC2 & 0.878 & & & \\
\hline & REC3 & 0.866 & & & \\
\hline \multirow{3}{*}{ Brand Trust } & BRT1 & 0.807 & \multirow{3}{*}{0.686} & \multirow{3}{*}{0.868} & \multirow{3}{*}{0.771} \\
\hline & BRT2 & 0.818 & & & \\
\hline & BRT3 & 0.859 & & & \\
\hline \multirow{4}{*}{$\begin{array}{l}\text { Purchase } \\
\text { Intention }\end{array}$} & PUI1 & 0.729 & \multirow{4}{*}{0.680} & \multirow{4}{*}{0.894} & \multirow{4}{*}{0.841} \\
\hline & PUI2 & 0.849 & & & \\
\hline & PUI3 & 0.876 & & & \\
\hline & PUI4 & 0.836 & & & \\
\hline
\end{tabular}

The result of the analysis is that the AVE value for all variables is the correlation of each variable. It is greater than the square and therefore all variables can be considered to have discriminant validity, as shown in Table 5.

\subsection{Verification of The Structural Model}

In this study, PLS was used as the data analysis method, taking into account the characteristics of the study (e.g. theoretical robustness, sample size and selfdevelopment of the questionnaire). The fit is high if the $\mathrm{R} 2$ value is 0.26 or more, medium if it is 0.26 to 0.13 and low if it is less than 0.13 . Brand trust $(0.234)$ can be evaluated as medium and purchase intention (0.347) can be evaluated as high. 
Table 5: Correlation and Discriminant Validity

\begin{tabular}{|c|c|c|c|c|c|c|}
\hline $\begin{array}{c}\text { Variable } \\
\text { name }\end{array}$ & AVE & Interactivity & $\begin{array}{c}\text { Access } \\
\text { Convenience }\end{array}$ & Recency & $\begin{array}{c}\text { Brand } \\
\text { Trust }\end{array}$ & $\begin{array}{c}\text { Purchase } \\
\text { Intention }\end{array}$ \\
\hline Interactivity & 0.690 & 0.830 & & & & \\
\hline $\begin{array}{c}\text { Access } \\
\text { Convenience }\end{array}$ & 0.647 & 0.473 & 0.805 & & & \\
\hline Recency & 0.741 & 0.279 & 0.406 & 0.860 & & \\
\hline Brand Trust & 0.686 & 0.326 & 0.391 & 0.389 & 0.828 & \\
\hline $\begin{array}{c}\text { Purchase } \\
\text { Intention }\end{array}$ & 0.680 & 0.291 & 0.364 & 0.517 & 0.589 & 0.825 \\
\hline
\end{tabular}

The research result model is shown in Fig. 2.

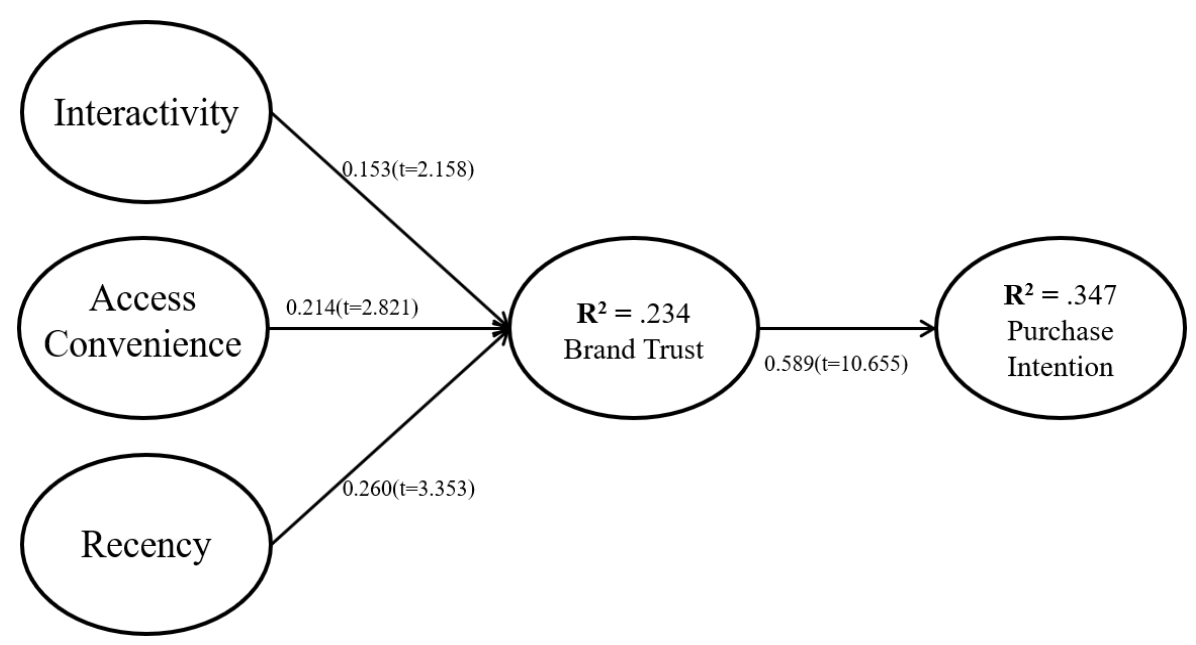

Fig. 2: The results of research model.

The results of the model analysis are presented below.

Hypothesis H1-1 "Interactivity has a positive (+) effect on brand trust" is statistically significant at the $95 \%$ significance level $(\mathrm{H} 1-1 ; \beta=0.153, \mathrm{t}=2.158$, $\mathrm{p}<0.05$ ) and therefore hypothesis $\mathrm{H} 1-1$ is valid, indicating that the higher the interactivity of the SNS, the higher the brand trust would be.

Hypothesis H1-2 "Access convenience has a positive (+) effect on brand trust" is statistically significant at the $95 \%$ level of significance $(\mathrm{H} 1-2 ; \beta=0.214, \mathrm{t}=2.821$, $\mathrm{p}<0.05)$ and therefore is valid, indicating that, the easier the accessibility of SNS, the higher the brand trust would be.

Hypothesis H1-3 "Recency has a positive (+) effect on brand trust" is statistically significant at the $95 \%$ level of significance $(\mathrm{H} 1-3 ; \beta=0.260, \mathrm{t}=3.353, \mathrm{p}<0.05)$ and therefore is valid, indicating that, the more recency the SNS is, the higher the brand 
trust is.

Hypothesis H2 "Brand trust has a positive (+) effect on consumers' purchase intentions" is statistically significant at the $95 \%$ level of significance $(\mathrm{H} 2 ; \beta=0.589$, $\mathrm{t}=10.655, \mathrm{p}<0.05$ ), therefore hypothesis $\mathrm{H} 2$ is valid. As a result, the higher brand trust is the higher purchase intentions are.

Table 6: Hypothesis Test Result Summary

\begin{tabular}{|c|c|c|c|c|c|}
\hline & $\begin{array}{c}\text { Cause } \\
\text { Variable }\end{array}$ & $\begin{array}{c}\text { Result } \\
\text { Variable }\end{array}$ & $\begin{array}{c}\text { Path } \\
\text { Coefficient }\end{array}$ & T-value & Result \\
\hline H1-1 & Interactivity & $\begin{array}{l}\text { Purchase } \\
\text { Intention }\end{array}$ & 0.153 & 2.158 & Accept \\
\hline $\mathrm{H} 1-2$ & $\begin{array}{c}\text { Access } \\
\text { Convenience }\end{array}$ & $\begin{array}{l}\text { Purchase } \\
\text { Intention }\end{array}$ & 0.214 & 2.821 & Accept \\
\hline $\mathrm{H} 1-3$ & Recency & $\begin{array}{l}\text { Purchase } \\
\text { Intention }\end{array}$ & 0.260 & 3.353 & Accept \\
\hline $\mathrm{H} 2$ & Brand Trust & $\begin{array}{l}\text { Purchase } \\
\text { Intention }\end{array}$ & 0.589 & 10.655 & Accept \\
\hline \multicolumn{6}{|c|}{$\mathrm{T}=1.960 * *(\mathrm{p}<0.05)$} \\
\hline
\end{tabular}

\section{Conclusion}

This study focused on Chinese consumers where a sample of Chinese people of all ages were surveyed in order to facilitate a comprehensive study of the impact of the characteristic elements of SNS (interactivity, access convenience, recency) on the purchase intentions of Chinese consumers in the beauty industry.

The findings of this thesis are as follows.

Hypothesis 1 was accepted which is based on the characteristic elements of SNS and brand trust. The characteristic elements of SNS such as interactivity, access convenience and recency all have a positive $(+)$ effect on brand trust. Hypothesis 2 on brand trust and consumer purchase intention was also accepted, which means brand trust has a positive (+) effect on consumer purchase intention.

Based on the results of the data analysis, the following conclusions were drawn.

First of all, interactivity, access convenience and recency among the characteristic elements of SNS have a positive (+) effect on brand trust. In other words, based on the interactivity of SNS, brands and businesses maintain timely communication and interaction with consumers on SNS, and users communicate with each other about their products on SNS. Based on the easy accessibility of SNS, users can easily register, $\log$ in and operate SNS, and can easily search for product information. Based on recency, SNS timely pushes relevant product content according to users' preferences and updates product information in real time, all of which can improve users' trust in the brand.

Second, brand trust has a positive (+) effect on consumers' willingness to 
purchase. In other words, online shopping can make consumers feel anxious and uneasy when they cannot fully understand the information and attributes of the products, and brand trust can largely eliminate consumers' negative emotions, thus prompting consumers' willingness to purchase or purchase behavior.

Now SNS is not only a social tool, but also a marketing tool and a platform for direct sales. The use of SNS by some outstanding companies has evolved from a relatively simple content marketing in the past to listening to the development of products and services through SNS, and directly completing purchases through SNS. Therefore, facing the trend of close integration of social and shopping, relevant companies need to work hard to create sharing and commenting platforms for target consumers, because comments and recommendations are the last step in the closed loop of social shopping and the starting point for triggering the next buying cycle.

China has entered a new era of consumption. The development of digitization has brought about the improvement of diversified consumption power. Consumers of different ages have different levels of mastery of digital technology, which promotes the evolution of new consumption patterns and consumption power. The whole process continues to change, but in general, the improvement of consumption power and the convenience of digitalization will be the general trend. In this environment, brand trust has become the eternal goal of winning the trust of consumers.

The limitation of this thesis is that it only starts on the characteristics of SNS, and there are many other elements of SNS characteristics that affect Chinese consumers' purchase intention. SNS is a social e-commerce platform for merchants and brand marketing. In addition to the three characteristics namely interactivity, access convenience, and recency, which are proposed in this paper, other scholars have also studied SNS characteristics such as entertainment, usefulness, and information provision, which are not considered in this thesis. In addition, consumers' personalities such as risk preference, hedonic and practical are not discriminated, and the types of products and internal and external clues factors of the products are not taken into consideration. For another example, questionnaire surveys are only distributed online, and offline collection methods are not used. The scope of data collection is not large enough, there are many invalid questionnaires, and the questionnaire samples are insufficient, thus the data has certain limitations. In the future, there should be a research on consumer orientation, and further expand the sample data and survey scope to strengthen the professionalism of the questionnaire results.

\section{References}

Choi, J. Y. (2017). The Effects of Information Characteristics of Daegu Tourism SNSs on Satisfaction and Re-visit Intention. Daegu University. Master's Thesis. 
Kim, D., \& Kim J. (2015). A Study on the Strategies for Improving User Satisfaction and Continuous Usage of Social Network Service. The Korea Society for Management Information Systems 17.1: 171-197.

Kim, J. G., \& Choi, H Y. (2014). A Study of Perceived Brand Quality on Customer Satisfaction, Brand Trust and Brand Loyalty. The Korean Society of Business Venturing 9.4: 163-173.

Kim, K. Y. (2020). The Effect of Functional, Experiential and Symbolic Benefit on Brand Loyalty: Based on Mediation Effect of Brand Trust and Brand Love. Inha University, Doctoral dissertation.

Kim, S. J., \& Lee, J. H. (2020). A Study of the Effects of the Selection Attributes of Lunchbox Stores Based on Dietary Lifestyles on Purchase Intention. Culinary Science \& Hospitality Research 26.1: 10-21.

Kim, Y. Y., \& Cho, W. J. (2016). The Effect of Domestic Airlines' Service Quality on Customers' Attitude toward Brand and Intention to Reuse. Korea Academic Society of Tourism Management 31.2: 495-514.

Jeon, J. Y. (2017). Impacts of SNS Characteristics on Business Performance: Focusing on the Degree of SNS Application in a Small Business. Kumoh National Institute of Technology, Master's Thesis.

Ju, S., \& Jung, L. S. (2019). The Effect of Exhibition Experience on the Intention of Purchase. International Journal of Smart Business and Technology 7.2: 39-44.

Jun, S. S., Jang, \& H. Y. (2014). The Impacts on Satisfaction and Purchase Intention of Using Digital Convergence Devices: Focusing on the Modulation Effects of Gender. Korea Internet Electronic Commerce Association 14.1: 69-87.

Jung, S. M., \& Kim, Y. H. (2020). A Study on the Effect of Corporate Sustainability Management Activities on Corporate Trust and Purchase Intention. Daehan Academy of Management Information Systems 39.1: 59-74.

Li, X. L. (2016). The Influence of Mobile Wechat's Information and Technical Characteristics on Purchase Intention. Yeungnam University, Master's Thesis.

Liu, Q. M. (2018). The Relationships between SNS Characteristics, Commitment, Trust, and Purchase Intention -Focus on Ashion Products. Gachon University, Master's Thesis. 
Oh, M. Y ., \& Kim, I. (2014). The Effect of Consumer Attitude toward Fashion Products on SNS's Characteristics to Purchase Intention and On-line Word of Mouth. The Korea Society of Fashion Design 14.1: 101-120.

Park, S. Y. (2019). Effects of SNS Marketing characteristics on consumers' brand attitude and purchase intention. Hoseo University, Master's Thesis.

Pei, F. (2017). The Effect of Consumer Perceived Risk on Perceived value, trust and brand loyalty-Focusing on online shopping malls. Gachon University, Doctoral dissertation.

The 47th Statistical Report on Internet Development in China. China Internet Network Information Center (2021): 17-37.

Tian, J. Y., \& Lee, Y. S. (2020). The Influence of Green Marketing Strategies of Chinese Fashion Companies on Brand Image and Purchase Intention of Consumers based on Green Attitudes. Asia-pacific Journal of Convergent Research Interchange, FuCoS 6.10: 97-107.

Wu, Y. L., \& Lee, Y. S. (2020). A Comparative Study on the Effects of Risk Perception and Quality Perception on the Purchase Intention of Fashion Products in Online and Offline Shopping. Asia-pacific Journal of Convergent Research Interchange, FuCoS 6.10: 109-121.

Xu, J., Wen, S. Y., \& Kim. (2021). The impact of SNS characteristic elements on customer purchase intention: focusing on Chinese beauty industry consumer. International Journal of Smart Business and Technology 9.2.

Yoo, S. S. (2019). A Study on the Components and Effects of Interactivity in SNS. Hongik University. Doctoral dissertation. 